\title{
CONTAMINATION OF SOIL AND PLANT BY THE HAZARIBAGH TANNERY INDUSTRIES
}

\author{
M.N. MONDOL ${ }^{1}$, A. ASIA, A.S. CHAMON AND S.M.A. FAIZ \\ Department of Soil, Water and Environment, \\ University of Dhaka, Dhaka-1000, Bangladesh
}

\begin{abstract}
An investigation was made at Hazaribagh Tannery area, comprising about 145 industries in Dhaka Metropolitan area. The analyses of soil and plant samples showed that heavy metals contribute significantly towards environmental contamssination resulting from industrial activities. Concentration of heavy metals $(\mathrm{Cr}, \mathrm{Zn}, \mathrm{Pb}, \mathrm{Cd}, \mathrm{Mn}, \mathrm{Fe}$ and $\mathrm{Ni}$ ) in soil and plant samples cross the MAC (Maximum allowable concentration) in both wet and dry season. In case of soil sample the highest concentration of $\mathrm{Cr}(172792 \mathrm{ppm})$ was found at main disposal point. Chromium, $\mathrm{Zn}, \mathrm{Pb}, \mathrm{Cd}, \mathrm{Mn}, \mathrm{Fe}$ and $\mathrm{Ni}$ concentrations at Hazaribagh plant samples respectively ranged from 171-1348, 247-777, 45-96, 1.66-2.17, $72-231,354-787$, and 18-38 ppm respectively in dry season and 75-1142, 209-691, 29$84,1.02-2.00,66-124,331-664,11-37$ ppm respectively in wet season. Concentration went down gradually with increasing distance from the main disposal point (spot 1). But again high concentration (150708 ppm of $\mathrm{Cr}$ ) was noted in spot 6 . Similar results were found for plant samples. High concentrations of heavy metals were found in plant samples which consequently affect food chain, which may be a major environmental concern.
\end{abstract}

Key words: Chromium, Copper, Lead, Cadmium, Zinc, Tannery wastes, Effluents, Heavy metal

\section{Introduction}

Soil and environment are under tremendous pressure due to industrial expansion and increased use of agricultural chemicals. Very few are aware of this globally important issue. The third world countries, especially Bangladesh are now in a vulnerable position. Bangladesh has now more than 30,000 industrial units (DOE 1991). With the advent of industrialization, wastes and effluent are being discharged into the natural ecosystems without treatment, creating pollution especially of heavy metals $(\mathrm{Cr}, \mathrm{Zn}, \mathrm{Pb}, \mathrm{Cd}, \mathrm{Fe}, \mathrm{Mn}$, Ni etc.).

Tannery industries of Hazaribagh situated in a heavily populated residential area discharge some 21,600 square meters of liquid wastes and 150 metric tons of solid waste everyday. These harmful wastes, including chromium, lead, sulphur, ammonium, salt and other materials, are severely polluting the capital city and the river Buriganga (Elahi et al. 2010). About $59 \%$ of the total wastage comes from processing of hides and skin and accumulates in the swamp-sludge. A recent research revealed that out of 270 tanneries in the country, except for two BATA and Dhaka Leather Complex-none of the tanneries has a treatment plant as required by the law (ImmamulHuq 1998).

${ }^{1}$ Corresponding author: mondol-bangladesh@hotmail.com 
Rice and wheat which were grown in a pot experiment in soils from the tannery area showed delayed maturity and stunting growth while rice showed late flowering and maturity with dark green colour (Chamon et al. 2005). In another experiment it was observed that application of tannery effluents to soils of differing textures resulted in reduction of rice yield and the adverse effect was more pronounced in light soils than in heavy soils (Elahi et al. 2010). The effluent was also found to negatively affect performance (Elahi et al. 2010). Similar results were also reported by Chamon et al. (2005). Reduction of rice yield production (43.6\%) due to heavy metal toxicity with hazaribagh soil was observed before by Chamon et al. (2005). Extreme concentration of $\mathrm{Cr}(27,000 \mathrm{ppm})$ around the vicinity and $1335 \mathrm{ppm} \mathrm{Cr}$ in $4 \mathrm{~km}$ down from the main disposal point were also reported by Nuruzzaman et al. (1995). Heavy matals concentration at hazaribagh area increased day by day. According to Ullah et al. (1999) at hazaribagh soil, $\mathrm{Cr}$ concentration increased to $25014 \mathrm{ppm}$.

Heavy metals, even in trace amounts, destroy enzymes and interfere with or inactivate enzymes of living cells (Rahman 1992) and hence their discharge into the environment must be carefully controlled and minimized.

Tannery industry is one of the most important and largest industrial businesses in Bangladesh. The 50 years old tannery complex comprising about 194 units are discharging their solid wastes and effluents to the channels, farmer's fields, in low lying areas, along road sides and water bodies without treatment and thereby causing environmental pollution especially due to heavy metals and organic toxins. The specific objectives of the research are to study the effects of wastes and effluents on the intensity of pollution to the soils by the heavy metals and to investigate the concentration of heavy metals in the plant samples causing contamination of the food chain.

\section{Materials and Methods}

Location of Hazaribagh tannery area: The Hazaribagh tannery complex situated in Dhaka municipality area (WSW) of the city are located inside the greater Dhaka flood protection embankment. The embankment was built in the year 1989 (Chowdhury et al. 1996). There are about 145 tannery factories in Hazaribagh residential area. Of the 270 tannery units, $90 \%$ are located on 25 hectares of land in Hazaribagh. Liquid waste makes its way on the other side of the embankment round the clock. This liquid waste ultimately goes into the water of the Buriganga river and causes immense harm to the fish and other aquatic organisms. Toxic materials in liquid waste seep into the surrounding cropland and underground water levels. Eventually, the tannery waste poisons the soil, water, plant and air round the clock. Tannery wastes also poison the health, houses and utensils of those situated around (Iwegbue et al. 2006).

Soils in Hazaribagh Area: The soil series around Hazaribagh belonging to Khaler Char (Soil Survey Staff 1975) remains seasonally flooded, up to 120-150 cm deep for more 
than 6 months and they are poorly to very poorly drained soils, developed in mainly medium textured Brahmaputra alluvium in permanently wet channels or depression on the old and young Brahmaputra, Meghna and Jamuna floodplains. Their profiles show little sign of development. General soil type is non-calcarious alluvium and Fluvaquent. The area inside the embankment is just organic wastes, on Jamuna alluvium, permanently wet by the effluents of the tannery factories.

Sampling: A total of 6 sampling points was chosen based on assumption of pollution intensity and types of samples. Spots are located inside and outside the embankment respectively. Spot 1 is considered the main disposal point and the increasing numbers of the spots indicate increasing distance from the main point. Soil and existing plant samples (with 3 replications) were collected twice (wet and dry seasons) on the basis of the local environmental conditions. The sampling spots were kept fixed throughout the whole sampling periods. Contaminated soil samples (with 3 replications) were collected from 0 $15 \mathrm{~cm}$ depths of a profile with the help of spade. Out of six, 3 soil samples were collected from inside the embankment and 3 soil samples were collected outside of the embankment. The sampling points were geo referenced with GPS (Geographical Positioning System) and marked on the map. GPS locations of sampling point are presented in Table 1.

Table 1. GPS location of sampling points (both in wet and dry seasons).

\begin{tabular}{ccccc}
\hline No of Sampling Site & Latitudes & Longitude & Soil & Plant \\
\hline 1 & $23^{0} 44.013^{\prime} \mathrm{N}$ & $90^{0} 21.807^{\prime} \mathrm{E}$ & $\sqrt{ }$ & $\mathbf{\times}$ \\
2 & $23^{0} 41.156^{\prime} \mathrm{N}$ & $90^{0} 21742^{\prime} \mathrm{E}$ & $\sqrt{ }$ & $\sqrt{ }$ \\
3 & $23^{0} 44.552^{\prime} \mathrm{N}$ & $90^{0} 21.604^{\prime} \mathrm{E}$ & $\sqrt{ }$ & $\sqrt{ }$ \\
4 & $23^{0} 44.673^{\prime} \mathrm{N}$ & $90^{0} 21.549^{\prime} \mathrm{E}$ & $\sqrt{ }$ & $\mathbf{x}$ \\
5 & $23^{0} 44.600^{\prime} \mathrm{N}$ & $90^{0} 21.279^{\prime} \mathrm{E}$ & $\sqrt{ }$ & $\sqrt{ }$ \\
6 & $23^{0} 44.501^{\prime} \mathrm{N}$ & $90^{0} 21.109^{\prime} \mathrm{E}$ & $\sqrt{ }$ & $\sqrt{ }$ \\
\hline
\end{tabular}

Soil samples collection and preservation: The soil samples collected were air dried, ground and screened to pass through $2 \mathrm{~mm}$ sieve and then mixed thoroughly to make it a composite sample. Dry root, grasses and other substances were discarded from the sample. Each soil sample was further ground and screened to pass through $1.0 \mathrm{~mm}$ and $2.0 \mathrm{~mm}$ sieve and was used for physical and chemical analyses.

Plant Samples collection and preservation: At main disposal point i.e. sampling point 1, all heavy metals concentration in soil was so high that no plants sample was found on that spot. The plants samples collected from other different spots are presented in Table 2. 
Table 2. List of collected plant samples.

\begin{tabular}{ccc}
\hline Spot No & Type of plants samples & Scientific Name \\
\hline Spot 2 & Grass & Cynodon dactylon \\
Spot 3 & Kalmi & Ipomoea aquatica \\
Spot 4 & Kalmi & Ipomoea aquatica \\
Spot 5 & Grass & Cynodon dactylon \\
Spot 6 & Water hyacinth & Eichhornia crassipes \\
& & \\
\hline
\end{tabular}

Plant samples were collected fresh from the polluted area in required amounts, wrapped in polyethylene bags and transported to laboratory and preserved at $+4^{0} \mathrm{C}$ for processing on the next day. All plant samples were air dried and placed in oven for drying at $70^{\circ} \mathrm{C}$ and then ground to powder for passing through a 2-mm sieve for chemical analysis. All plant samples were kept in plastic containers for chemical analyses.

\section{Determination of physical soil properties}

Soil Texture: The particle size distribution of the soils was measured by the hydrometer method (ÖNORM 1991). The textural class was determined from the Marshalls triangular co-ordinates as described by the United States Department of Agriculture (USDA 1975).

Moisture content of soil: The percent of moisture content of the soil was determined by known amount of soil in an electric oven at $105^{\circ} \mathrm{C}$ for 25 hours until constant weight was obtained and moisture percentage was calculated from the sample as described by Black (1965).

\section{Determination of chemical and physicochemical properties of Soil}

Soil pH: The $\mathrm{pH}$ of the soil was measured electrochemically using a corning glass electrode $\mathrm{pH}$ meter as suggested by Jackson and Alloways (1962). The ratio of soil to water was $1: 2.5$.

Electrical conductivity: The electrical conductivity of the soil was measured at a soil: water ratio of 1:2 by an EC meter.

Organic Carbon and organic matter: Organic carbon was determined by wet oxidation method of Walkley and Black (1934) as describe by Piper (1950) and Jackson and Alloways (1962). The organic matter content of the soils was determined by multiplying the percentage of organic carbon with the conventional "Van-Bemmelen's Factor" of 1.72 (Piper 1950).

Available and total Nitrogen: Available and total nitrogen of the soil were determined by "Micro Kjeldhal"s distillation method as described by Black (1965). 
Total Phosphorus, Potassium, Calcium, Magnesium and Sulfur: The total P, K, Ca and $\mathrm{Mg}$ were extracted by digesting the soil with aqua regia (Vdlufa 1975). The total phosphorous content of the soil was determined colorimetrically at $470 \mathrm{~nm}$ using a spectrophotometer (UV-1200) after developing the yellow colour with vanadomolybdate as described by Jackson and Alloways (1962). Total $\mathrm{Ca}$ and $\mathrm{Mg}$ were measured titrimetrimetrically by EDTA compleximetry method (Jackson and Alloways 1962). Total and exchangeable $\mathrm{Na}$ and $\mathrm{K}$ were measured by flame photometer.

\section{Total heavy metals in soil and plant samples}

Digestion of soil samples with aqua regia $\left(\mathrm{HCl}: \mathrm{HNO}_{3}\right)$ : Soil samples were digested with $\mathrm{HCl}+\mathrm{HNO}_{3}$ (3:1) mixture under closed system (Blum et al. 1996). Aqua regia decomposes nearly almost all complex forming soil particles (clay minerals, organic substances, oxides, etc.) through which most of the ions go into solution and can be measured quantitatively.

Digestion of plant samples with $\mathrm{HNO}_{3}-\mathrm{HClO}_{4}$ : $0.2 \mathrm{~g}$ of finely ground plant sample was weighed and digested with $20 \mathrm{ml}$ conc. $\mathrm{HNO}_{3}$ and $10 \mathrm{ml}$ conc. $\mathrm{HClO}_{4}$ (Blum et al. 1996).

Measurements of Total heavy metals: All the trace elements were measured in the extracts with the help of an Atomic Absorption Spectrophotometer (AAS), model no AA421.

\section{Results and Discussion}

\section{Physical, Chemical and Physicochemical properties of soils}

Moisture content: Soil characteristics of Hazaribagh tannery area are presented in Table 3 . The moisture content $(\%)$ of the soil at various sampling points ranged from 18 to 28 and 22 to $36 \%$ in dry season and wet season, respectively (Table 3 ).

$p H$ : Soil $\mathrm{pH}$ did not vary appreciably between sampling points and ranged from 7.06 to 8.32 and 6.95 to 8.47 in dry and wet seasons, respectively (Table 3). Nuruzzaman et al. (1998) and Immamul Huq (1998) reported that $\mathrm{pH}$ of the top soil at Hazaribagh tannery area were 7.3 and 7.2. A wide range of $\mathrm{pH}$ from 7.2 to 12.0 and 7.3 to 9.9 was observed by Nuruzzaman et al. (1998) in tannery effluents and waste water, respectively, which did not affect soil $\mathrm{pH}$ (7.3). This might be due to buffering capacity of these soils containing high amounts of organic matter. Various tanning and coloring materials are mainly responsible for wide range of $\mathrm{pH}$ variation.

Particle size: The soil of Hazaribagh belongs to Khaler Char soil series and there was no noticeable difference in particle size fraction as well as sand, silt and clay percentage between the wet and dry season soil samples (Table 3).

Eh: Eh values of the soil samples ranged from -233 to -350 and -274 to $-350(\mathrm{mV})$ in dry and wet seasons, respectively (Table 3 ). Eh values with minus sign at different spots 
indicate highly reduced condition and under reduced condition almost all heavy metal remain available to aquatic flora and fauna.

Organic matter: The organic matter content (\%) in various sampling points was found to range from 4.9 to 12.6 and 3.8 to 16.2 , in dry season and wet season, respectively (Table $3)$. In dry season maximum accumulation was observed at sampling point $1(12.6 \%)$ and gradually decreasing values were observed from source point 1 to downstream and outside the embankment. Same findings were also observed in wet season where the highest value of organic matter was observed at the source point i.e at the sampling point $1(16.2 \%)$. Nuruzzaman et al. (1998) reported a value of organic matter (\%) of $10.3 \%$ at source point. Deposition and decomposition of huge quantities of tannery effluents and solid wastes are mainly responsible for the organic matter content of the soil.

EC (Electrical Conductivity): Higher EC means higher amounts of soluble Na, Caand $\mathrm{Mg}$. EC greater than $4 \mathrm{dS} / \mathrm{m}$ is harmful for plant growth (Ponnamperuma 1985). The EC $(\mathrm{dS} / \mathrm{m})$ in various sampling point ranged from 3.5 to 5.9 and 3.7 to $7.1 \mathrm{dS} / \mathrm{m}$ in dry season and wet season,respectively (Table 3). Higher values of EC at Hazaribagh tannery area were also reported before (Ullal et al. 1999 and Elahi et al. 2010).

Table 3. Physical, Chemical and physicochemical properties of soils.

\begin{tabular}{|c|c|c|c|c|c|c|c|c|c|}
\hline \multicolumn{10}{|c|}{ Dry season } \\
\hline $\begin{array}{l}\text { Spot } \\
\text { No }\end{array}$ & $\begin{array}{l}\% \\
\text { Moisture }\end{array}$ & $\mathrm{pH}$ & $\begin{array}{l}\% \\
\text { sand }\end{array}$ & $\begin{array}{l}\% \\
\text { silt }\end{array}$ & $\begin{array}{l}\% \\
\text { clay }\end{array}$ & $\begin{array}{l}\text { Eh } \\
(\mathrm{mV})\end{array}$ & OM\% & $\begin{array}{c}\mathrm{EC} \\
(\mathrm{dS} / \mathrm{m})\end{array}$ & $\begin{array}{c}\text { CEC } \\
(\mathrm{Meq} / 100 \mathrm{~g})\end{array}$ \\
\hline 1 & 19.2 & 8.04 & 35.3 & 46 & 18.7 & -333 & 12.6 & 5.9 & 38.2 \\
\hline 2 & 25.12 & 7.70 & 31.6 & 45.8 & 22.6 & -320 & 10.8 & 4.3 & 31.9 \\
\hline 3 & 22.5 & 8.32 & 40 & 42.9 & 17.1 & -338 & 10.1 & 4.5 & 29.6 \\
\hline 4 & 18.12 & 7.72 & 36.9 & 42.6 & 20.5 & -350 & 9.63 & 4.8 & 29.9 \\
\hline 5 & 27.5 & 7.21 & 30.6 & 49.8 & 19.6 & -235 & 6.9 & 3.9 & 20.6 \\
\hline 6 & 24.42 & 7.06 & 40.5 & 42.8 & 16.7 & -233 & 4.9 & 3.5 & 20.3 \\
\hline \multicolumn{10}{|c|}{ Wet season } \\
\hline Spot & $\%$ & & $\%$ & $\%$ & $\%$ & Eh & & $\mathrm{EC}$ & CEC \\
\hline No & Moisture & $\mathrm{pH}$ & sand & silt & clay & $(\mathrm{mV})$ & OM\% & $(\mathrm{dS} / \mathrm{m})$ & $(\mathrm{Meq} / 100 \mathrm{~g})$ \\
\hline 1 & 32.2 & 7.23 & 35 & 46.9 & 18.1 & -300 & 16.2 & 6.2 & 32.3 \\
\hline 2 & 35.12 & 8.47 & 31.3 & 45.7 & 23 & -350 & 11.3 & 6.8 & 34.4 \\
\hline 3 & 36.2 & 7.56 & 40.9 & 42.9 & 16.2 & -348 & 11.2 & 7.1 & 30.5 \\
\hline 4 & 28.9 & 7.87 & 32.2 & 47.3 & 20.5 & -348 & 9.1 & 4.2 & 29.1 \\
\hline 5 & 29.6 & 6.95 & 30.6 & 39.8 & 29.6 & -274 & 6.25 & 3.7 & 22.3 \\
\hline 6 & 21.6 & 7.25 & 40.5 & 44.5 & 15 & -296 & 3.8 & 4.2 & 26.7 \\
\hline
\end{tabular}

CEC (cation exchange capacity): CEC (Meq/100g of the soil) at various sampling points of Hazaribagh tannery area were found to range from 20.3 to 38.2 and 22.3 to 34.5 (Meq/100g) for dry season and wet season in soil respectively (Table 3 ). The high CEC was related to their high organic matter content as reported by Nuruzzanman et al. (1995). 
Total $N$ and Available $N$ : High concentrations of total $\mathrm{N}$ as well as available $\mathrm{N}$ were observed in the surface soil $(0$ to $15 \mathrm{~cm})$ at Hazaribagh tannery area in both wet and dry season (Table 4). Tannery wastes increased the total $\mathrm{N}$ concentration of surface soils (Nuruzzanman et al. 1995 and Chamon et al. 2005). The higher accumulation was observed in dry season (Table 4) (January) and lower in wet season (August).

Table 4. Physical, Chemical and physicochemical properties of soils.

\begin{tabular}{|c|c|c|c|c|c|c|c|c|c|c|c|}
\hline \multicolumn{12}{|c|}{ Dry season } \\
\hline $\begin{array}{c}\text { Spot } \\
\text { No }\end{array}$ & $\begin{array}{c}\text { Total } \\
\mathrm{N}\end{array}$ & $\begin{array}{c}\text { Available } \\
\mathrm{N}\end{array}$ & $\begin{array}{c}\text { Total } \\
\mathrm{P}\end{array}$ & $\begin{array}{c}\text { Available } \\
\mathrm{P} \\
\end{array}$ & $\begin{array}{c}\text { Total } \\
\mathrm{K}\end{array}$ & $\begin{array}{c}\text { Available } \\
\text { K }\end{array}$ & $\begin{array}{c}\text { Total } \\
\text { S }\end{array}$ & \multicolumn{3}{|c|}{ Exchangeable } & $\mathrm{Na}$ \\
\hline \multicolumn{12}{|c|}{$\mathrm{ppm}$} \\
\hline 1 & 2478 & 960 & 3690 & 6.9 & 1854 & 148 & 1587 & 6.8 & 2.8 & 0.4 & 40.9 \\
\hline 2 & 2158 & 821 & 3244 & 5.8 & 1485 & 125 & 1481 & 6.3 & 2.3 & 0.2 & 35 \\
\hline 3 & 1965 & 185 & 2963 & 7.2 & 1250 & 98 & 1125 & 5.1 & 1.8 & 0.3 & 32.2 \\
\hline 4 & 1258 & 89 & 2717 & 7.6 & 1145 & 89 & 1025 & 5.6 & 1.2 & 0.4 & 31.3 \\
\hline 5 & 1325 & 93 & 2561 & 5.2 & 1006 & 75 & 658 & 6.4 & 1.9 & 0.4 & 30.6 \\
\hline 6 & 1357 & 96 & 1583 & 2.4 & 654 & 28 & 745 & 7.2 & 3.6 & 0.5 & 40.5 \\
\hline \multicolumn{12}{|c|}{ Wet season } \\
\hline Spot & Total & Available & Total & Available & Total & Available & Total & $\mathrm{Ca}$ & $\mathrm{Mg}$ & $\mathrm{K}$ & $\mathrm{Na}$ \\
\hline No & $\mathrm{N}$ & $\mathrm{N}$ & $\mathrm{P}$ & $\mathrm{P}$ & $\mathrm{K}$ & $\mathrm{K}$ & $\mathrm{S}$ & \multicolumn{4}{|c|}{ Exchangeable } \\
\hline \multicolumn{12}{|c|}{$\mathrm{ppm}$} \\
\hline 1 & 2145 & 652 & 3602 & 6.1 & 1569 & 245 & 1365 & 5.2 & 2.9 & 0.3 & 26.2 \\
\hline 2 & 2123 & 478 & 3230 & 5.5 & 1405 & 124 & 1145 & 5.7 & 2.1 & 0.6 & 21.5 \\
\hline 3 & 1658 & 143 & 2978 & 6.3 & 1236 & 87 & 1258 & 5.1 & 1.9 & 0.2 & 12.3 \\
\hline 4 & 1332 & 92 & 2689 & 7.2 & 1128 & 98 & 1198 & 5.8 & 2.1 & 0.2 & 3.2 \\
\hline 5 & 1258 & 84 & 2798 & 4.9 & 984 & 114 & 695 & 6.8 & 2.8 & 0.6 & 1.3 \\
\hline 6 & 1378 & 92 & 1545 & 3.6 & 965 & 16 & 845 & 6.3 & 2.5 & 0.1 & 5.3 \\
\hline
\end{tabular}

Total $P$ and Available $P$ : High concentrations of total $\mathrm{P}$ and available $\mathrm{P}$ were observed in the soil at Hazaribagh tannery area in both dry and wet seasons. This observed higher concentration might be due to use of higher amounts of various phosphate salts, which are used in various steps in tanning process. Compared to dry season, a lower value of total $\mathrm{P}$ and available $\mathrm{P}$ was observed in wet season ranging from 1545 to $2978 \mathrm{ppm}$ and 2.4 to $7.2 \mathrm{ppm}$ for total $\mathrm{P}$ and available $\mathrm{P}$, respectively (Table 4).

Total $K$ and Available $K$ : The concentrations of total $\mathrm{K}$ at various sampling points of Hazaribagh tannery area ranged from 654 to 1854 ppm and 965 to 1569 ppm for dry and wet seasons in soil, respectively (Table 4).

Total S: The concentrations of total $\mathrm{S}$ in soil at various sampling points of study area were found to range from 658 to $1587 \mathrm{ppm}$ and 695 to $1365 \mathrm{ppm}$ in dry and wet seasons, respectively (Table 4). Higher value of total S (1587 ppm) was observed at sampling point 1 which gradually decreased with increasing distance and the lowest value (654 $\mathrm{ppm}$ ) of total $\mathrm{S}$ was observed at sampling point 6 . Similar results were observed in case 
of wet season. Observation of lower value of total $\mathrm{S}$ in wet season might be due to dilution by rain water.

Exchangeable $\mathrm{Na}, \mathrm{K}, \mathrm{Ca}$ and $\mathrm{Mg}$ : Higher amounts of exchangeable $\mathrm{Na}, \mathrm{K}, \mathrm{Ca}$ and $\mathrm{Mg}$ in soil were recorded at different sampling points at Hazaribagh tannery area (Table 4). The high concentration of EC in different spots within the embankment were attribute to the increase in soluble salts particularly $\mathrm{Na}, \mathrm{K}, \mathrm{Ca}$ and $\mathrm{Mg}$ from the tannery effluent, values exceeding 4dS/m which is the harmful limit for rice seedling establishment (Nuruzzanman et al. 1995).

\section{Heavy metals in Soil at Hazaribagh tannery area}

Chromium in soil in dry and wet seasons: Chromium concentration at Hazaribagh sampling area ranged from 42792 to 172792 and 26654 to 148446 ppm in dry and wet season, respectively (Table 5). Highest $\mathrm{Cr}$ concentration was observed in main disposal point i.e. at spot 1 and decreasing value was observed with increasing distance from the discharge point. Significant differences were found among different sampling spots.

High Cr concentration (150708 ppm) observed at spot 6 was significantly different from other spots except spot 1, during dry season. Similar results were also observed in wet season (Table 5).Ullah et al. (1999) reported 25014 ppm Cr concentration at Hazaribagh area. Previously similar findings were also reported at Hazaribagh area (Chamon et al. 2005 and Elahi et al. 2010). Chromium concentration of 59333 ppm in soil was reported by Elahi et al. (2010). Relatively lower value of $\mathrm{Cr}$ was observed at the same sampling point in wet season. This might be due to dilution of $\mathrm{Cr}$ in soil by rain water in wet season. High $\mathrm{Cr}$ concentration may occur due to use of higher amount chromium sulphate $\left(\left[\mathrm{Cr}\left(\mathrm{H}_{2} \mathrm{O}\right)_{6}\right]_{2}\left(\mathrm{SO}_{4}\right)_{3}\right)$, regarded as one of the most efficient and effective tanning agent, during liming, pickling and curing stage.

$\mathrm{Cr}$ concentration at 6 sampling points (both in dry and wet season) cross the MAC (Maximum allowable concentration) for soil (100 mg/kg) (Kloke 1980). It is evident that very high level of $\mathrm{Cr}$ (Table 5) along with other heavy metals were found in spot 1 which serves as a settling basin and gradually concentration went down with increasing distance of spots from spot 1. But again high concentration was noted in spot 6 (Table 5). This spot may be previously contaminated before 1989, when there was no embankment to protect this area from the tannery waste and effluents. The result indicates that the soil is extremely polluted with $\mathrm{Cr}$, even outside the embankment (Nuruzzanman et al. 1998).

As stated earlier, the tannery discharges the effluents and wastes into the river system. Consequently, there is a large area of sludge alongside the flood protection embankment and the liquid wastes are dumped into the river through a flood control regulator-cumsluice near Hazaribagh. During monsoon months, the flood protection embankment 
protect Dhaka from heavy flooding while making it difficult to flash out the waste water, thereby creating a great environmental hazards in the neighborhood of the tanneries. On the other hand, during the dry season the waste water is flushed out into the river, causing pollution of the river water (spot 6) and ultimately affecting the aquatic flora and fauna. Likewise the dumping of the solid wastes is seriously affecting the soil and plants, besides vitiating the air, ground water and human health (Immamul Huq 1998).

Zinc $(\mathrm{Zn})$ concentration in soil indry and wet seasons: Total zinc concentration at Hazaribagh sampling area ranged from 1000 to 1950 ppm and 1264 to 1896 ppm in dry and wet seasons respectively (Table 5). Highest $\mathrm{Zn}$ concentration was observed in main disposal point i.e. at spot 1 and decreasing value were observed with increasing distance from the discharge point. Ullah et al. (1999) reported $365 \mathrm{ppm}$ of $\mathrm{Zn}$ concentration at Hazaribagh area soil. Similar findings $(290 \mathrm{ppm})$ were also reported by Nuruzzaman et al. (1998). Elahi et al. (2010) found 3000 ppm Zn concentration at Hazaribagh area bulk soil (Table 5). Zn concentration at 6 sampling points (both dry and wet season) cross the MAC (Maximum allowable concentration) for soil (300 mg/kg) (Kloke 1980).

Lead $(\mathrm{Pb})$ in soil in dry and wet seasons: Lead concentration at Hazaribagh sampling area was found to range from 80.5 to 157 and 24.17 to $144.57 \mathrm{ppm}$ in dry and wet seasons, respectively (Table. 5). Highest $\mathrm{Pb}$ concentration was observed in main disposal point i.e. at spot 1 and decreasing value was observed with increasing distance. Significant differences were found among different sampling spots. $131.0 \mathrm{ppm} \mathrm{of} \mathrm{Pb}$ concentrationwas observed at spot 6 outside of the embankment, which was significantly different from other spots except spot 1 and 2, during dry season. The value was different in case of wet season. Significant differences were observed among sampling point (Table 5). The tests of significance of differences at of different sampling points were calculated by DMRT at 5\% level. 44.2 and $68.1 \mathrm{ppm}$ of $\mathrm{Pb}$ concentration was reported by Ullah et al. (1999) and Nuruzzanman et al. (1998), respectively.

Relatively higher $\mathrm{Pb}$ concentrations were found at spot 6 in dry and wet seasons (131.0 and $114.57 \mathrm{ppm})$, respectively. That spot may be previously contaminated before 1989 when there was no embankment to protect this area from tannery waste or huge amounts of waste water and effluents are now continuously being added from other different industries (Ullah et al. 1999).

Lead concentration at 6 sampling points (both dry and wet seasons) crossed the MAC for soil (100 mg/kg) (Kloke 1980). 
Table 5. Chromium $(\mathrm{Cr})$, Zinc $(\mathrm{Zn})$ and Lead $(\mathrm{Pb})$ concentration $(\mathrm{ppm})$ in soil at various sampling points of Hazaribagh area in dry and wet seasons.

\begin{tabular}{ccccccc}
\hline Spot No & \multicolumn{2}{c}{$\mathrm{Cr}(\mathrm{ppm})$} & \multicolumn{2}{c}{$\mathrm{Zn}(\mathrm{ppm})$} & \multicolumn{2}{c}{$\mathrm{Pb}(\mathrm{ppm})$} \\
\hline & $\begin{array}{c}\text { Dry } \\
\text { season }\end{array}$ & $\begin{array}{c}\text { Wet } \\
\text { season }\end{array}$ & Dry season & $\begin{array}{c}\text { Wet } \\
\text { season }\end{array}$ & Dry season & Wet season \\
\hline Spot 1 & $172792 \mathrm{a}$ & $148446 \mathrm{a}$ & $1950 \mathrm{a}$ & $1896 \mathrm{a}$ & $157 \mathrm{a}$ & $145 \mathrm{a}$ \\
Spot 2 & $71542 \mathrm{~b}$ & $71238 \mathrm{~b}$ & $1878 \mathrm{a}$ & $1765 \mathrm{a}$ & $130 \mathrm{ab}$ & $142 \mathrm{a}$ \\
Spot 3 & $87375 \mathrm{~b}$ & $52488 \mathrm{bc}$ & $1778 \mathrm{~b}$ & $1065 \mathrm{~b}$ & $104 \mathrm{~b}$ & $43 \mathrm{~b}$ \\
Spot 4 & $42792 \mathrm{~b}$ & $26654 \mathrm{~d}$ & $1780 \mathrm{~b}$ & $299 \mathrm{~b}$ & $81 \mathrm{c}$ & $32 \mathrm{~b}$ \\
Spot 5 & $59875 \mathrm{~b}$ & $40821 \mathrm{~cd}$ & $1586 \mathrm{~b}$ & $200 \mathrm{c}$ & $75 \mathrm{c}$ & $24 \mathrm{~b}$ \\
Spot 6 & $150708 \mathrm{a}$ & $56238 \mathrm{bc}$ & $1264 \mathrm{c}$ & $1150 \mathrm{~b}$ & $131 \mathrm{ab}$ & $115 \mathrm{a}$ \\
Mean & 97514 & 63411 & 1706 & 1062 & 113 & 83 \\
\hline
\end{tabular}

Means followed by same letter in a column do not differ significantly from each other at $5 \%$ level by DMRT.

Cadmium $(C d)$ in soil in dry and wet seasons: Cadmium concentration at Hazaribagh sampling area ranged from 2.33 to $1.5 \mathrm{ppm}$ and 0.75 to $2.10 \mathrm{ppm}$ in dry and wet season, respectively (Table 6). The highest $\mathrm{Cd}$ concentration was observed in main disposal point i.e. at spot 1 and decreasing value was observed with increasing distance from discharge point. Significant differences were found among different sampling spots except spot no 1, 3 and 4. $1.50 \mathrm{ppm}$ of $\mathrm{Cd}$ concentration was observed at spot 6 which were not significantly different from other spots (Spot no 3 and 4) during dry season. The value was different in case of wet season. Significant difference was observed among sampling points (Table 6). The tests of significance of different sampling point were calculated by DMRT at 5\% level.

Lower value of $\mathrm{Cd}$ concentration observed in wet season might be due to dilution of $\mathrm{Cd}$ of soil by rain water. Cadmium concentration may be higher due to use of cadmium sulphate during curing and finishing stage. Huge amount of cadmium sulphate and cadmium phosphate are used to polish the hide and skin. Cadmium concentration at 6 sampling points (both in dry and wet season) did not cross the MAC for soil $(3.00 \mathrm{mg} / \mathrm{kg}$ ) (Kloke1980).

Manganese (Mn) in soil in dry and wet seasons: Manganese concentration at Hazaribagh sampling area ranged from 333 to 733 and 183 to $601 \mathrm{ppm}$ in dry and wet seasons, respectively (Table 6). The highest $\mathrm{Mn}$ concentration was observed in main disposal point i.e. at spot 1 and decreasing value was observed with increasing distance. Significant differences were found among different sampling spots. Manganese (Mn) concentration of $561 \mathrm{ppm}$ was observed at spot 6 which was significantly, different from other spots, during dry season. The value was different in case of wet season. No 
significant differences were observed among sampling point 1, 2, 3, 6 and 4, 5 (Table 6). The tests of significance of different sampling point were calculated by DMRT at 5\% level. Ullah et al. (1999) had reported 263 ppm Mn concentration at Hazaribagh area and $425 \mathrm{ppm}$ of Mn concentration in soil was reported by Nuruzzaman et al.(1998). Manganese concentration at 6 sampling points (both in dry and wet season) did not cross the MAC for soil (1000 mg/Kg) (Kloke 1980).

Iron $(\mathrm{Fe})$ in soil in dry and wet seasons: Iron concentration at Hazaribagh sampling area ranged from 21081 to 55914 ppm and 21498 to 50991 ppm in dry and wet seasons, respectively (Table 6). Fe concentration at spot 1 (both dry and wet season) crossed the MAC for soil $(50,000 \mathrm{mg} / \mathrm{kg}$ ) (Chiroma et al. 2012)

Table 6. Cadmium, $\mathrm{Mn}$ and $\mathrm{Fe}$ concentration ( $\mathrm{ppm}$ ) in soil at various sampling points of Hazaribag area in dry and wet seasons.

\begin{tabular}{ccccccc}
\hline Spot No & \multicolumn{2}{c}{ Cd Concentration (ppm) } & \multicolumn{2}{c}{ Mn Concentration (ppm) } & \multicolumn{2}{c}{ Fe Concentration $(\mathrm{ppm})$} \\
\hline & Dry season & Wet season & Dry season & Wet season & Dry season & Wet season \\
\hline Spot 1 & $2.33 \mathrm{a}$ & $2.10 \mathrm{a}$ & $733 \mathrm{a}$ & $601 \mathrm{a}$ & $55914 \mathrm{a}$ & $50991 \mathrm{a}$ \\
Spot 2 & $1.5 \mathrm{~b}$ & $2.0 \mathrm{a}$ & $641 \mathrm{a}$ & $562 \mathrm{a}$ & $45787 \mathrm{a}$ & $47914 \mathrm{a}$ \\
Spot 3 & $1.75 \mathrm{ab}$ & $1.250 \mathrm{~b}$ & $633 \mathrm{a}$ & $521 \mathrm{a}$ & $37412 \mathrm{a}$ & $28414 \mathrm{~b}$ \\
Spot 4 & $1.79 \mathrm{ab}$ & $1.83 \mathrm{ab}$ & $366 \mathrm{~b}$ & $374 \mathrm{~b}$ & $35437 \mathrm{~b}$ & $23414 \mathrm{~b}$ \\
Spot 5 & $1.25 \mathrm{c}$ & $0.58 \mathrm{c}$ & $333 \mathrm{~b}$ & $183 \mathrm{~b}$ & $21081 \mathrm{~b}$ & $21497 \mathrm{~b}$ \\
Spot 6 & $1.50 \mathrm{~b}$ & $0.75 \mathrm{c}$ & $560 \mathrm{ab}$ & $448 \mathrm{ab}$ & $25416 \mathrm{~b}$ & $24247 \mathrm{~b}$ \\
\hline Mean & 1.68 & 1.40 & 566 & 454 & 36841 & 32746
\end{tabular}

Means followed by same letter in a column do not differ significantly from each other at $5 \%$ level by DMRT.

Nickel (Ni) in soil in dry and wet seasons: Nickel concentration at Hazaribagh sampling area ranged from 37 to 355 and 31 to $256 \mathrm{ppm}$ in dry and wet seasons respectively, (Fig.1). The highest Ni concentration was observed in main disposal point (i.e. at spot 1) which crossed the MAC for soil $(50 \mathrm{mg} / \mathrm{Kg}$ ) (Kloke 1980) and decreasing value was observed with increasing distance. Significant differences were found among different sampling spots. At spot 6 (outside of the embankment), $142 \mathrm{ppm}$ of nickel (Ni) was observed which were significantly different from other spots, during dry season. Spot 6 may be previously contaminated before 1989 when there was no embankment to protect this area from tannery waste or huge amounts of waste water and effluents are now continuously added from other different industries (Ullah et al. 1999).

The concentration was different in case of wet season. There were no significant differences observed at various sampling points. The tests of significance of different sampling point were calculated by DMRT at $5 \%$ level. 


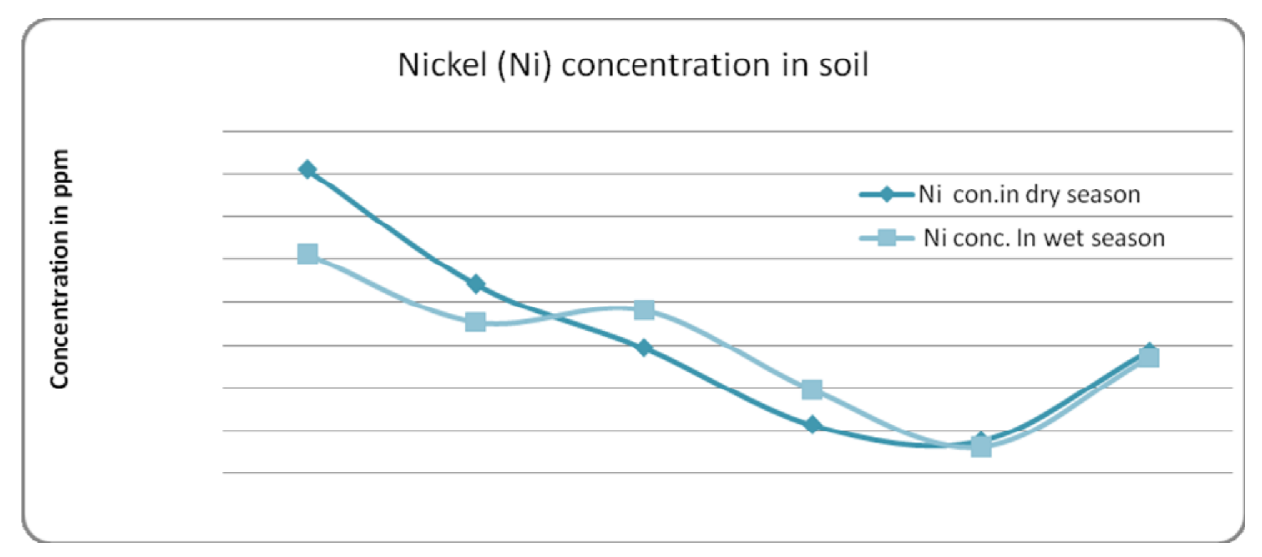

Fig.1. Ni concentration (ppm) in Soil at various sampling points of Hazaribagh area in dry and wet season.

\section{Heavy metal concentrations in plant samples at Hazaribagh tannery area}

Chromium ( $\mathrm{Cr}$ ) in plant samples in dry and wet seasons: Chromium concentrations in plant samples at Hazaribagh sampling area ranged from 171 to 1348 and 75 to $1142 \mathrm{ppm}$ in dry and wet seasons, respectively (Table 7). Chromium concentrations in dry season were 684, 564, 243, 171 and 1348 ppm in sampling point 2 (grass), 3 (kalmi), 4 (kalmi), 5 (grass) and 6 (water hyacinth), respectively (Table 7). Higher $\mathrm{Cr}$ concentration (1348 ppm) was observed in water hyacinth (spot 6) which was significantly different from other spots. Significant differences were found among other different sampling spots expect sampling point 2 and 3 i.e grass and kalmi. Similar results were also observed in wet season (Table 7). The tests of significance of different sampling point were calculated by DMRT at 5\% level. Water hyacinth might be contaminated by various chromium salt that were used in tannery industries or huge amounts of waste water and effluents which are now continuously being added from other different industries. Due to variation of plant species uptake of heavy metals by plants also varies differently as reported by Chamon et al. (2005).

Relatively lower value of $\mathrm{Cr}$ was observed in all type of plant samples at the same sampling point in wet season. The lowest $(75 \mathrm{ppm})$ and the highest (1142 ppm) concentrations of $\mathrm{Cr}$ was found at sampling point 5 and 6 i.e in grass and water hyacinth. Significant differences were found among different sampling spots. Chromium concentration observed at wet season might be due to dilution of available $\mathrm{Cr}$ for plant by rainfall. Elahi et al. (2010) reported $6591 \mathrm{ppm} \mathrm{Cr}$ in the root of water hyacinth and 756 ppm $\mathrm{Cr}$ in the shoot of water hyacinth at Hazaribagh area. Similar findings were also reported by Nuruzzaman et al. (1998). Similar findings were reported by Mark et al.(1995) for the uptake of heavy metals by water hyacinth in Lake Chivers which is fed by the two rivers being considered here. As long as the rate of absorption by the root is 
higher than the rate of translocation to the stem and leaves, the metal concentration will be higher in the root than the tops (Mark et al. 1995). Chromium concentration at 6 sampling points (both dry and wet seasons) crossed MAC for plant (1-2 mg/kg) (Lake et al. 1984).

Zinc $(\mathrm{Zn})$ in plants in dry and wet seasons: Zinc concentrations in plant samples at Hazaribagh sampling area ranged from 247 to 777 and 209 to 691 ppm in dry and wet seasons, respectively (Table 7).

Lead $(\mathrm{Pb})$ in plant samples in dry and wet seasons: Lead concentrations in plant samples at Hazaribagh sampling area ranged from 44.55 to 95.6 and 28.83 to $84.17 \mathrm{ppm}$ respectively, in dry and wet seasons (Table 7).

Cadmium $(C d)$ in plant samples in dry and wet seasons: Cadmium concentrations in plant samples at Hazaribagh sampling area ranged from 1.66 to 2.17 and 1.02 to 2.00 ppm in dry and wet season, respectively (Table 7).

Cadmium concentration at 6 sampling points (both dry and wet seasons) crossed the MAC for plant (5-10mg/kg) (Lake et al. 1984 and Sauerbeck 1982).

Manganese $(\mathrm{Mn})$ in plant samples in dry and wet seasons: Manganese concentrations in plant samples at Hazaribagh sampling area ranged from 72 to 231 and 66 to 124 ppm in dry and wet season, respectively (Table 8).

Iron $(\mathrm{Fe})$ in plants in dry and wet seasons: Iron concentrations in plant samples at Hazaribagh sampling area found to range from 354 to 787 and 331 to 664 ppm in dry and wet season, respectively (Table 8).

Nickel (Ni) in plants in dry and wet seasons: Nickel concentrations in plant samples at Hazaribagh sampling area were found to range from 18 to 38 and 11 to 37 ppm in dry and wet seasons, respectively (Fig. 2).

Table 7. Chromium, $\mathrm{Zn}$ and Pbconcentrations (ppm) in plants at various sampling point of Hazaribagh area both in dry and wet seasons.

\begin{tabular}{cccccccc}
\hline Spot No & $\begin{array}{c}\text { Type of } \\
\text { plants } \\
\text { samples }\end{array}$ & \multicolumn{2}{c}{$\begin{array}{c}\text { Cr Concentration } \\
(\mathrm{ppm})\end{array}$} & \multicolumn{2}{c}{ Zn Concentration (ppm) } & \multicolumn{2}{c}{$\begin{array}{c}\text { Pb Concentration } \\
(\mathrm{ppm})\end{array}$} \\
\cline { 3 - 8 } & Dry season & Wet season & Dry season & Wet season & Dry season & Wet season \\
\hline Spot 2 & Grass & $684 \mathrm{~b}$ & $475 \mathrm{a}$ & $498 \mathrm{~b}$ & $472 \mathrm{~b}$ & $96 \mathrm{a}$ & $84 \mathrm{a}$ \\
Spot 3 & Kalmi & $564 \mathrm{~b}$ & $410 \mathrm{a}$ & $384 \mathrm{~b}$ & $312 \mathrm{~b}$ & $76 \mathrm{a}$ & $65 \mathrm{~b}$ \\
Spot 4 & Kalmi & $243 \mathrm{a}$ & $375 \mathrm{c}$ & $247 \mathrm{c}$ & $209 \mathrm{c}$ & $70 \mathrm{~b}$ & $58 \mathrm{~b}$ \\
Spot 5 & Grass & $171 \mathrm{c}$ & $75 \mathrm{c}$ & $318 \mathrm{~b}$ & $331 \mathrm{~b}$ & $45 \mathrm{~b}$ & $29 \mathrm{c}$ \\
Spot 6 & Water & $1348 \mathrm{a}$ & $1142 \mathrm{a}$ & $777 \mathrm{a}$ & $691 \mathrm{a}$ & $80 \mathrm{a}$ & $25 \mathrm{c}$ \\
& hyacinth & 602 & 495 & 445 & 403 & 73 & 52 \\
\hline
\end{tabular}

Means followed by same letter in a column do not differ significantly from each other at $5 \%$ level by DMRT. 
Table 8. $\mathrm{Cd}, \mathrm{Mn}$ and $\mathrm{Fe}$ concentration (ppm) in plants at various sampling point of Hazaribagh area both in dry and wet seasons.

\begin{tabular}{|c|c|c|c|c|c|c|c|}
\hline \multirow{2}{*}{$\begin{array}{l}\text { Spot } \\
\text { No }\end{array}$} & \multirow{2}{*}{$\begin{array}{l}\text { Type of } \\
\text { plants } \\
\text { samples }\end{array}$} & \multicolumn{2}{|c|}{$\mathrm{Cd}(\mathrm{ppm})$} & \multicolumn{2}{|c|}{ Mn (ppm) } & \multicolumn{2}{|c|}{$\mathrm{Fe}(\mathrm{ppm})$} \\
\hline & & Dry season & Wet season & Dry season & Wet season & Dry season & Wet season \\
\hline Spot 2 & Grass & $2.17 \mathrm{a}$ & $2.01 \mathrm{a}$ & $231 \mathrm{a}$ & $124 \mathrm{a}$ & $787 \mathrm{a}$ & $472 \mathrm{a}$ \\
\hline Spot 3 & Kalmi & $2.08 \mathrm{a}$ & $2.0 \mathrm{a}$ & $196 \mathrm{ab}$ & $116 \mathrm{a}$ & $637 \mathrm{a}$ & $534 \mathrm{a}$ \\
\hline Spot 4 & Kalmi & $1.75 \mathrm{a}$ & $1.5 \mathrm{a}$ & $102 \mathrm{ab}$ & $108 \mathrm{a}$ & $354 \mathrm{a}$ & $331 \mathrm{a}$ \\
\hline Spot 5 & Grass & $1.66 \mathrm{a}$ & $1.02 \mathrm{a}$ & $72 \mathrm{~b}$ & $66 \mathrm{a}$ & $683 \mathrm{a}$ & $664 a$ \\
\hline Spot 6 & $\begin{array}{c}\text { Water } \\
\text { hyacinth }\end{array}$ & $2.17 \mathrm{a}$ & $2.00 \mathrm{a}$ & $167 \mathrm{ab}$ & $74 \mathrm{a}$ & $381 \mathrm{a}$ & $239 a$ \\
\hline Mean & & 1.97 & 1.704 & 153 & 98 & 568 & 448 \\
\hline
\end{tabular}

Means followed by same letter in a column do not differ significantly from each other at $5 \%$ level by DMRT.

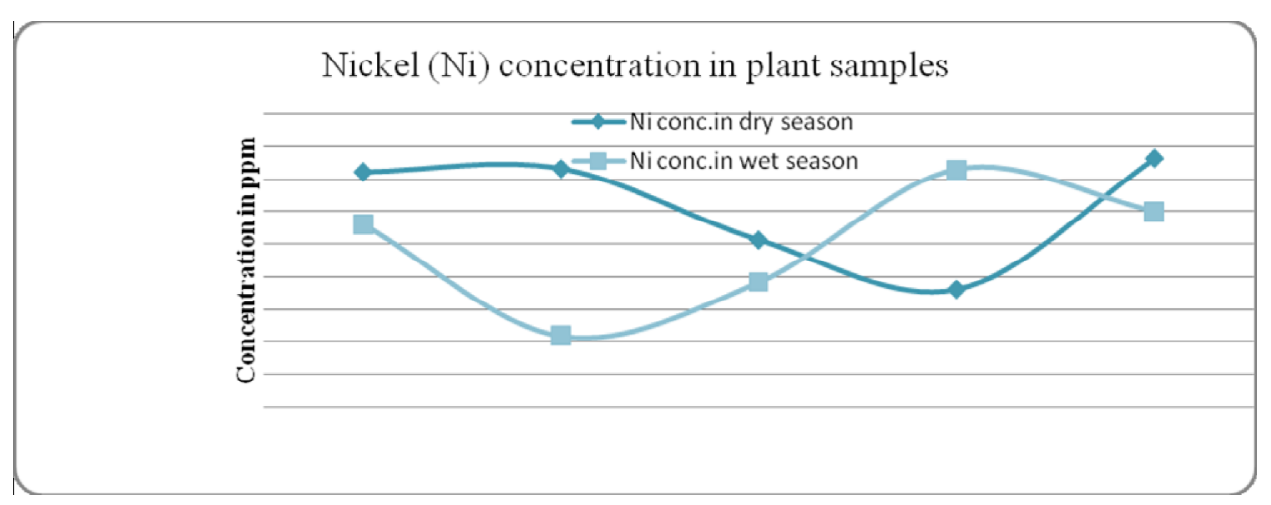

Fig. 2. Ni concentration (ppm) in plants at various sampling point of Hazaribagh area both in dry and wet seasons.

\section{Acknowledgements}

The authors are thankful to the Department of Soil, Water and Environment, University of Dhaka, Bangladesh, for providing facilities for analyses of samples.

\section{References}

Black, C.A. 1965. Methods of soil analysis. Part 1. Am. Soc. Ago., Inc, Publshe. Madiso. Wisconsn, USA. pp.121-132.

Blum, W.E.H., H. Spiegeland W.W. Wenzel.1996. Bodenzutstandsinventur. Konception, Durchführung und Bewertung, EmpfehlungenZurVereinheitlichung der Vorgangsweise in Österreich.Bundesministeriumfür Land und Forstwirtschaft, Wien. $2^{\text {nd }}$ edition. pp. 102103.

Chamon, A.S., M.H. Gerzabek, M.N. Mondol, S.M. Ullah, M. Rahman and W.E.H. Blum. 2005. Heavy metal uptake into crops on polluted soils of Bangladesh. I. Influence of crop and crop varieties. J. Comm. Soil Sci. Plant analysis. 36: 907-924. 
Chiroma, T.M., R.O. Ebewele and F.K. Hymore. 2012. Levels of Heavy Metals $(\mathrm{Cu}, \mathrm{Zn}, \mathrm{Pb}, \mathrm{Fe}$ and $\mathrm{Cr}$ ) in Bushgreen and Roselle Irrigated with Treated and Untreated Urban Sewage Water. Int. Res. J. Environment Sci. 1(4): 1-7.

Chowdhury, F.J., S.M. Imamul Huq and M. Aminul Islam.1996. Accumulation of various pollutants by some aquatic macrophytes found in the Buriganga River. Proceeding of the $25^{\text {th }}$ Bangladesh science conference.DOE 1992. Training Manual on Environmental management. pp. 121-145.

DOE (Department of Environment). 2002. Environmental Quality Standards for Bangladesh. Report. pp. 11-14.

Elahi, S.F., A.S. Chamon, B. Faiz, M.N. Mondol and M.H. Rahaman. 2010. Specification of heavy metals in soils, plants and water in Bangladesh. Bangladesh. J. Agric. and Environ. 5 (2):79-97.

Immamul Huq, S.M. 1998. Critical environmental issues relating to tanning industries in Bangladesh. In. "Towards better management of soils contaminated with tannery wastes" Proceedings of a workshop at the Tamil Nadu Agri. University, Coimbatore, India, 31, January to 4 February. R. Naidu, I.R. Willett, S. Mahimairajah, R. Kookana and K. Ramasamy (eds).pp.22-28

Iwegbue, C.M.A., F. Egobueze and K.Opuene. 2006. Preliminary assessment of heavy metals levels of soil of an oil field in the Nigar Delta. Nigeria. Inti. J. Enviro. Sci.Technol. 3 (2): 167-172.

Jackson, A.P. and B.J. Alloways. 1962. The transfer of Cd from agricultural soils to the human food chain "In Biogeochemistry of Trace Metals".Advances in Trace Substances Research. D.C. Adriano, Ed. (Boca Raton: CRC press Inc.) Pp. 109-158.

Kloke A. 1980. Orientierungslaten fur tolerierGesamtgehalteeiniger.Element in Kulturboder.Mitteilungen der VDLUfA.Heft1-3: 9-11

Lake, D.L., P.W.W. Kirk and J.N. Lester. 1984. Fractionation. Characterization and speciation of heavy metals in sewage and sludge amended soil. A review. J. Environ. Quality.13: 175183.

Mark, F., Zaranyika and Timothy Ndapwadza. 1995. Uptake of Ni, Zn, Fe, Co, Cr, Pd, Cu and Cd by water hyachinth in mukuvisi and many ame rivers ; J. Environ. Sci. Health, A.(30) 1:157-1469.

Nuruzzaman, M.,M.H. Gerzabek and S.M. Ullah.1995. Studis on heavy metal and microbiological pollution of soils, sediments and water systems in and around Dhaka City.Berichtan die Österr. Akademieder Wissenschaften, ÖFZS. 123 - 321

Nuruzzaman, M., M.H. Gerzabek, A. Islam, M.H. Rashid and S.M. Ullah. 1998. Contamination of Soil environment by the tannery industries. . Bangladesh J. Soil. Sci. 25(1): 1-10.

ÖNORM. 1991. General Waste Water Emision prescription in the main drainage channel and cannel system. Nr. 179: 184-206.

Piper. 1950. Soil and PlantAnalysis. Hassel Press. Adelaide. Australia. pp. 143.

Ponnamperuma, F.N.N. 1985. Chemical kinetics of wet land rice soils relative to soil fertility. In wetland soils: Characterizations, Classification and Agriculture, IRRI, Philipine.

Rahman, K. 1992. Industrial pollution and control for sustainable development. Training manual on environmental management in Bangladesh. Department of Environment, pp. 184-206.

Sauerbeck, D.1982. Welche Schwermetallghalte in Pflanzendurfennichtuberschrittenwarden. Um Wachstumsbeein trachtigungen Zuvermeiden? Landw. Forsch. Sonderheft 39. Kongressband. Pp. 108-129.

Soil Survey Staff. 1975. Reconnaissance Soil Survey Report of Dhaka District. Published by Dept. of Soil Survey, Ministry of Agriculture, Govt. of the People's Republic of Bangladesh. pp. 21-45.

Ullah, S. M., M.H. Gerzabek, M.N. Mondol, M.M. Rashid and M. Islam. 1999. Heavy metal pollution of soils and water and their transfer into plants in Bangladesh. In. Proc. of extended Abstracts. 5th International Conference on the Biogeochemistry of Trace 
Elements (Wenzel, W. W., D.C. Adriano; B. Alloway; H.E. Doner; C. Keller; N.W. Lepp; M. Mench; R. Naidu and G.M. Pierzynski. (eds) Vienna, Austria. I: 260-61UNB, November, 2003. pp.96-108

USDA (Soil conservation Service, Soil Survey Staff), 1975. Soil Taxonomy: A basic system of Soil Classification for making and interpreting Soil Surveys. Agriculture Handbook 436, USDA, SCS, U.S. Government Printing Office, Washington, D.C.

Vdlufa, 1975. Kunigswasserauszug (Vorschlag des AgrikulturChemischen Institutes der Universität Bonn) Beurteilung der Siedlungsabfallkomposte (SAK) alsProduktionsmittel der Landwirtschaft Heft. 4/1975: 731.

Walkley, A. and I.A. Black, 1934. An examination of the Degtjareff method for determining soil organic matter and a proposed modification of the chromic acid titration method. Soil Sci. 37: 29-38. 